\title{
Florida's Citrus Canker Eradication Program (CCEP): Benefit-Cost Analysis ${ }^{1}$
}

\author{
Marisa L. Zansler, Thomas H. Spreen and Ronald P. Muraro²
}

Rapid expansion and integration of international trade, increased tourism, and changes in methods of production in recent decades have increased the likelihood of the introduction of invasive species to U.S. (United States) agriculture. Invasive species can have adverse environmental and/or economic impacts when introduced into a region. Economic impacts include marketing, production, and trade implications.

One such invasive species imposing adverse economic impacts to the Florida citrus industry is a bacterial disease known as citrus canker (caused by Xanthomonas axanopodis pv. citri). Citrus canker causes lesions on the leaves, stems, and fruit of citrus trees. The disease adversely affects the proportion of fruit intended for the fresh market, serves to weaken citrus trees, and leads to a reduction in yields and higher costs of production.

The Citrus Canker Eradication Program (CCEP) was implemented in the mid-1990s in an attempt to establish guidelines for averting the spread of the disease. Currently there is no biological or chemical cure for citrus canker. All infected trees and citrus trees within a radius of 1900 feet of an infected tree must be eradicated (1900-foot rule). On-site decontamination of grove workers, field equipment, and packinghouses is also mandatory.

The current effort to eradicate citrus canker from the industry, the CCEP, has been mired in controversy associated with public opinion and legal action. A benefit-cost analysis was conducted to determine whether the CCEP is, indeed, a useful policy tool in combating the economic ramifications associated with citrus canker.

In this paper, an economic analysis of the CCEP on the Florida citrus industry is conducted through employment of a benefit-cost analysis of retaining the current policy. A benefit-cost analysis of the CCEP in Florida is developed using the predicted values of the benefits and the costs associated with the policy. The actual expenditures of implementation to-date are weighed against the estimated loss of

1. This is EDIS document FE531, a publication of the Department of Food and Resource Economics, Florida Cooperative Extension Service, Institute of Food and Agricultural Sciences, University of Florida, Gainesville, FL. Published March 2005. Please visit the EDIS website at http://edis.ifas.ufl.edu.

Note: This one of a series on the economic impacts of citrus canker on Florida's citrus industry. The series is available at: http://edis.ifas.ufl.edu/TOPIC_CCEP.

2. Marisa L. Zansler, Economist, Policy Analysis and Development, USDA/APHIS, Washington, D.C.; Thomas H. Spreen, Professor and Chair, Department of Food and Resource Economics, University of Florida, Gainesville, FL; and Ronald P. Muraro, Professor and Extension Economist, Department of Food and Resource Economics, Citrus Research and Education Center, Lake Alfred, FL, Florida Cooperative Extension Service, Institute of Food and Agricultural Sciences, University of Florida, Gainesville, FL.

The Institute of Food and Agricultural Sciences (IFAS) is an Equal Employment Opportunity - Affirmative Action Employer authorized to provide research, educational information and other services only to individuals and institutions that function without regard to race, creed, color, religion, age, disability, sex, sexual orientation, marital status, national origin, political opinions or affiliations. For information on obtaining other extension publications, contact your county Cooperative Extension Service office. Florida Cooperative Extension Service / Institute of Food and Agricultural Sciences / University of Florida / Larry R. Arrington, Interim Dean 
revenue and the cost savings associated with an industry with pervasive citrus canker in an attempt to assess the net benefits of the policy.

Florida is the largest producer of citrus in the United States, accounting for approximately 77 percent of total production each year. Florida is also the largest producer of grapefruit on the world market, and shares a majority of the world's orange juice market with Brazil. Events affecting the Florida citrus industry jeopardize its position in the world market.

Estimation of the benefits associated with the CCEP includes an assessment of the processed orange juice market, the fresh and processed grapefruit market, and the specialty citrus market, and an analysis of increased costs of production if citrus canker were to become endemic to Florida.

Estimation of the costs associated with the CCEP includes expenditures on compensation to producers for eradicated groves, expenditures on compensation to homeowners for eradicated trees, expenditures on citrus canker research, and legal costs.

\section{Estimation of the Benefits of the CCEP}

The benefits of CCEP are estimated under the assumption that, without CCEP, citrus canker would become endemic in Florida. Economic impacts are based on the expert opinion of scientists who have studied the horticultural effects of canker on citrus trees grown outside of the United States. The likely marketing impacts on the fresh fruit industry can be estimated from experiences in other countries, such as Argentina where citrus canker is endemic.

The perceived benefit of the CCEP is avoiding the following consequences associated with an endemic citrus canker situation:

- Increased costs of production. The industry would face an increase in the cost of production resulting from increased copper bactericide spraying to mitigate the effect of citrus canker on tree productivity and fruit appearance, and the cost of establishing windbreaks for certain varieties to slow the spread and reduce disease infection.
- Decline in yields. Citrus canker can weaken the vitality of a tree, leading to a reduction in per acre yields due to increased fruit drop. The establishment of windbreaks reduces tree density per acre, thus reducing per acre yields. Lower packout rates, the effect of citrus canker on external fruit appearance, would substantially reduce the proportion of fruit suitable for the fresh market. The impact of citrus canker on packout has not been documented in published research. Experience in other countries, however, suggests that endemic citrus canker would have a strong negative effect on the external appearance of fruit and, thereby, result in substantially lower packout. In this paper, it is assumed that packouts would be reduced by one-third. For example, historical packout rates for fresh grapefruit sent to the domestic market have been approximately 60 percent (Brown, Spreen, and Muraro, 1999). Under this assumption, endemic citrus canker would result in a one-third decrease to a packout rate of 40 percent.

- Loss of market access. Florida fresh fruit shippers would lose market access to other citrus growing regions, including Texas, California, and Western Europe.

Quantifying the benefits of the CCEP requires a multi-faceted approach, including analysis of both the fresh and processed citrus markets. In the market models, prices and quantities reported by the Florida Agricultural Statistics Service (FASS) and the Citrus Administrative Committee (CAC) are used as reference points for spatial equilibrium mathematical programming models. These models are calibrated to replicate the 1999-2000 marketing year.

\section{The Decision to Retain or Discard the CCEP}

Considering the controversy surrounding the CCEP, should Florida abandon the program and choose to live with citrus canker in the absence of any biological or chemical methods effective in eliminating the disease from the citrus industry? The main argument hinges on whether the CCEP will prove to be beneficial in the long run for the citrus industry. One of the arguments posed by opponents 
of the CCEP was the contention that the industry would not incur losses of a sufficient magnitude to outweigh the costs of the CCEP. The question then becomes whether or not to discard the CCEP. If the CCEP were abandoned, it is assumed that citrus canker would become endemic to the citrus industry in Florida. Avoiding revenue losses and additional production costs associated with endemic citrus canker are benefits of the current policy. Actual expenditures by federal and state agencies of implementing the CCEP are the costs associated with the current policy. These expenditures include outlays for eradication, research, grower compensation, and legal fees.

The annual benefits of the CCEP are outlined in Table 1. The primary estimated benefits of the CCEP are decreasing revenue losses associated with reduced yields while increasing market access and cost savings. Eradication means avoiding additional costs associated with establishing windbreaks and additional copper spray at pre-bloom and petal fall. Specialty fruit, it is estimated, actually experiences a net gain in revenue associated with endemic citrus canker because of the significant increase in fresh on-tree prices associated with decreased shipments of certain varieties to the fresh market. The net gain reduces the benefits associated with the CCEP by $\$ 44.5$ million.

Estimated benefits of the CCEP associated with avoidance of revenue loss include the processed orange market, the fresh and processed grapefruit markets, and the specialty citrus fruit market. Total avoided revenue loss is estimated to be $\$ 84.9$ million annually. The estimated benefits of the CCEP associated with cost savings are the additional costs incurred to producers in the processed orange market, field run processed grapefruit, packinghouse grapefruit, and specialty fruit production in an endemic citrus canker industry. Total cost savings associated with the CCEP are estimated at $\$ 169.2$ million (EDIS FE532).

Actual expenditures of the CCEP are outlined in Table 2. These are the actual costs incurred via policy implementation to-date, including the legal expenditures resulting from challenges to the program. The total cost of the eradication program as of June of 2004 is estimated at $\$ 477$ million, including the decontamination compliance procedures, inspection fees, destruction of infected and/or exposed trees, and compensation for lost trees to homeowners. Both the State of Florida and the United States Department of Agriculture (USDA) have incurred these costs. The Florida budget for fiscal year 2004-05 recommends \$44 million to continue citrus canker eradication efforts. It is not known if the USDA will continue to contribute to eradication efforts after its initial \$25 million investment. Expenditures to compensate growers for destroyed trees were appropriated in 2000, and expenditures for production losses were appropriated in 2001. Compensation to producers for lost production on eradicated groves due to citrus canker infection or exposure was approximately $\$ 76.8$ million for fiscal years 2000 and 2001. This value is based on estimates provided by the USDA's Animal and Plant Health Inspection Service (APHIS). Payment to producers is split evenly over the two years. Compensation to producers for lost production on eradicated groves due to citrus canker infection or exposure was approximately $\$ 28.4$ million for fiscal years 2003 and 2004. Payments of $\$ 11.8$ million and $\$ 16.6$ million were paid out in 2003 and 2004, respectively. Although they represent activity throughout the study, the legal expenses were incurred in 2000, and research expenditures granted by the federal government were incurred in 2001 .

If the eradication program were allowed to proceed without any further legal interruption, the remainder of the infected or exposed trees should have been cleared by the end of 2005 (DPI, 2004). The procedures outlined in the CCEP require that the sentinel surveys continue for an additional two years after the last positive citrus canker find. Under these circumstances, it is expected that the eradication program will continue on until January of 2008 (Florida E-Budget, 2004). The costs of the program are not expected to exceed $\$ 22.8$ million (Florida E-Budget, 2004). The estimated benefit-cost analysis of proceeding with the CCEP, assuming a discount rate of ten percent, is depicted in Table 3 . The results indicate that the net benefits of the CCEP, measured as the net present value of revenue loss avoidance and cost savings less the net present value of the costs of the CCEP, are positive, suggesting that Florida 
should retain the eradication program. The infinite discounted net benefits of the CCEP are estimated using a geometric series as follows:

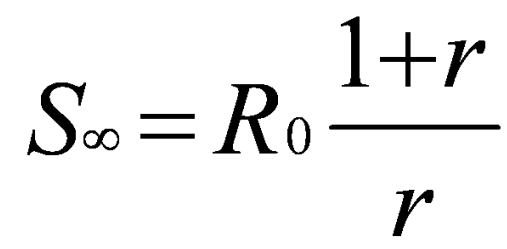

where $\mathrm{R}_{0}$ is the benefit associated with the CCEP, which is comprised of annual revenue loss and cost savings associated with an endemic citrus canker industry, and $r$ is the discount rate. The estimation is then adjusted to reflect the beginning period it appears in the analysis, which is 2008 . The benefit of the CCEP associated with the period after its completion is approximately $\$ 891$ million. The discounted net benefits of the CCEP over time are roughly $\$ 2.3$ billion.

A sensitivity analysis of the discount rate used in the benefit-cost analysis of the CCEP is outlined in Table 4. The results indicate that positive net benefits are associated with the eradication program at various discount rates, suggesting that assumptions used to assess the policy are not marginal. Discounted net benefits increase by nearly $\$ 2.5$ billion to $\$ 4.7$ billion at a discount rate of five percent. Discounted net benefits decrease by $\$ 792.5$ million to approximately $\$ 1.5$ billion at a higher discount rate of 15 percent.

In addition to conducting a sensitivity analysis on the discount rate, this study allows for a sensitivity analysis on the predicted values of the benefit-cost analysis. The predicted values of this study are evaluated allowing for a 25 percent margin of error in estimation. The estimated benefits and costs are evaluated in Table 5 across a range of $0.75,1.00$, and 1.25. The estimation is based on a discount value of ten percent.

The results of the sensitivity analysis indicate how the discounted net benefits of the CCEP vary if costs and benefits range from 25 percent lower to 25 percent higher than the original estimation. If the predicted value of annual benefits of the CCEP were actually 25 percent lower and the predicted value of annual costs of the CCEP were actually 25 percent greater, the discounted net benefit of the CCEP would still exceed the estimated CCEP costs, yielding a net benefit of $\$ 1.5$ billion. On the other end of the spectrum, if the predicted value of annual benefits of the CCEP were actually 25 percent greater and the predicted value of annual costs of the CCEP were actually 25 percent less than estimated, the discounted net benefit of the CCEP would be $\$ 3$ billion.

The estimated costs associated with the CCEP were assessed using the actual reported expenditures. The focus of the sensitivity analysis relies on the assumptions used to obtain the predicted benefits of the model. It is more likely that the predicted benefits in this analysis are undervalued. Recall that the assessment of predicted benefits of the CCEP relied on estimated changes in revenue and costs savings. Estimated benefits of the CCEP do not include situations where producers lose access such as with export packinghouses in which they grow, harvest, pack, and ship most of their fruit to foreign markets. It also does not include changes in the labor market resulting from less fruit available for harvest.

In addition, the predicted benefits in this analysis do not account for changes in demand associated with consumer perception of the risk that citrus canker may pose to their health. Although citrus canker will not adversely affect human health, the mere image of consuming a product that is visually unappealing may have an effect on the demand for Florida citrus.

\section{The Effect of Stop-and-Go on the Efficiency of the CCEP}

The analysis of the previous section includes the sunk costs of legal fees associated with the legal challenges to the CCEP. As suggested elsewhere in this document, the events surrounding the necessity of legal fees (i.e., injunctions placed on tree eradication, the so-called "stop-and-go" routine) contributed to additional years of the program. During the periods in which eradication was halted, sentinel surveys were suspended. It is unknown, precisely, how much the disease spread during this period. It is known, however, that early in 2000, state officials adopted an aggressive eradication campaign designed to mitigate the spread of the disease based 
on the 1900-foot rule (APHIS, 2003). By October of 2000 , contractors hired to destroy trees within infected areas were cutting as many as 5,000 trees per day in Miami-Dade and Broward Counties. At that time, Deputy Commissioner of Agriculture Craig Meyer fully anticipated containment of the disease by late January of 2001 (Crawford, 2000). Around the same time, legal action began a process that came to be known as the "stop-and-go" approach to eradication.

A benefit-cost analysis of the CCEP is conducted under the assumption that eradication efforts would have been successful by the end of 2000. It is assumed that the benefits of the program remain unchanged since they are independent of legal actions associated with the program. Table 5 lists the yearly expenditures on the CCEP without the "stop-and-go" approach to eradication. The total cost of the eradication program through fiscal year 2002 is estimated to be $\$ 322$ million, including the decontamination compliance procedures, inspection fees, destruction of infected and/or exposed trees, and compensation for lost trees to homeowners. Since expenditures on grower compensation for destroyed trees and lost production were appropriated in 2000 and 2001 for eradicated groves due to citrus canker infection or exposure in earlier years, the appropriated \$76.8 million is still split evenly over 2000 and 2001. It is assumed that research expenditures, funded by the federal government, are still incurred in 2001 for this study. The procedures outlined in the CCEP would still require the continuation of sentinel surveys for an additional two years after the last positive citrus canker find. Under these circumstances, it is estimated that the eradication program would last until January of 2003 (Florida's E-Budget, 2004). The costs of the program are not expected to exceed $\$ 22.8$ million per year (Florida's E-Budget, 2004).

In Table 6, the estimated benefit-cost analysis of proceeding with the CCEP in the absence of the "stop-and-go" approach to eradication is depicted assuming a discount rate of ten percent. Discounted net benefits increase by more than $\$ 216$ million over time (from $\$ 2.256$ billion to $\$ 2.472$ billion). Discounted costs associated with the CCEP decline by 45 percent (from $\$ 367$ million to $\$ 200$ million).

\section{Conclusion}

The results of the benefit-cost analysis clearly suggest that benefits of the CCEP outweigh the costs of the program, thereby recommending that the program continue. The total net benefits of the program in the long run are estimated to be $\$ 2.3$ billion. The discounted net benefits of the program proved to be even more persuasive of the effectiveness of the CCEP without the "stop-and-go" approach to eradication. If the CCEP had been allowed to continue without interruption from the beginning, the total net benefits of the program in the long run would have been $\$ 2.5$ billion.

If the CCEP were repudiated, citrus canker would become endemic to the industry. The industry would not only face the loss of net benefits associated with the program, but the entire structure of the industry would be changed forever.

Results of this analysis suggest that swift action is the best policy if citrus canker were somehow reintroduced into Florida in the future. If another breakout should occur after Florida has been certified canker-free, the best policy would be immediate eradication according to the 1900 -foot rule. It is best to eradicate as quickly as possible to minimize the costs to Florida, the federal government, and the citrus industry. In addition, the need to eradicate residential trees, if any, would be minimal in the future.

The effects of the 2004 hurricane season add a new unknown in the CCEP economic analysis, since the citrus canker bacteria disease is spread by rain-driven wind. Results for the economic analysis were developed in June of 2004 before Hurricanes Charley, Francis, and Jeanne passed through Florida. Continuation of the CCEP beyond 2008 would require a new study to estimate the economic impact of the additional costs of the CCEP along with the losses incurred by Florida's citrus industry.

\section{References}

Animal and Plant Health Inspection Service (APHIS). 2003. Citrus Canker. Washington DC: 
United States Department of Agriculture. Available online at

http://www.aphis.usda.gov/ppq/ep/citruscanker.

Muraro, R.P., F.M. Roka, and T.H. Spreen. 2001. Grower Costs of Having Citrus Canker in Florida. Electronic Data Information Source (EDIS) FE286. Department of Food and Resource Economics, UF/IFAS, University of Florida, Gainesville, FL (June).

Zansler, M.L. 2004. The Economic Impacts to an Industry Associated with an Invasive Species: The Case of Citrus Canker in Florida. Ph.D. dissertation, Department of Food and Resource Economics, University of Florida, Gainesville, FL (August).

Zansler M.L., T.H. Spreen, and R.P. Muraro. 2005. Florida's Citrus Canker Eradication Program (CCEP): Summary of Annual Costs and Benefits. Electronic Data Information Source (EDIS) FE532. Department of Food and Resource Economics, UF/IFAS, University of Florida, Gainesville, FL (February). 
Table 1. Estimated annual benefits associated with the CCEP. ${ }^{a}$

\begin{tabular}{|c|c|c|}
\hline \multirow[t]{2}{*}{ Citrus Market } & \multicolumn{2}{|c|}{ Estimated Annual Revenue Losses } \\
\hline & On-Tree Revenue & F.O.B. Revenue \\
\hline & \multicolumn{2}{|c|}{---------------- $\$ 1,000$------------------- } \\
\hline Processed Oranges & $(\$ 20,437)$ & $(\$ 35,120)$ \\
\hline Red and White Seedless Grapefruit & $(\$ 13,228)$ & $(\$ 71,510)$ \\
\hline Fresh and Processed Specialty Citrus Fruit & $\$ 44,490$ & $\$ 10,856$ \\
\hline Net Estimated Annual Revenue Gains (Loss) & $\$ 10,825$ & $(\$ 95,774)$ \\
\hline \multirow[t]{3}{*}{ Total Annual Estimated Revenue Losses } & & $\$ 84,949$ \\
\hline & \multicolumn{2}{|c|}{ Estimated Annual Additional Costs of Production } \\
\hline & & ---- $\$ 1,000$---- \\
\hline Processed Oranges & & $\$ 14,357$ \\
\hline Red and White Seedless Grapefruit & & $\$ 72,688$ \\
\hline Fresh and Processed Specialty Citrus Fruit & & $\$ 82,201$ \\
\hline \multicolumn{2}{|c|}{ Estimated Annual Benefit of CCEP Associated Cost Savings } & $\$ 169,246$ \\
\hline
\end{tabular}

Table 2. Yearly expenditures associated with the CCEP. ${ }^{a}$

\begin{tabular}{|c|c|c|c|c|c|}
\hline Year & $\begin{array}{c}\text { Producer } \\
\text { Compensation }\end{array}$ & $\begin{array}{c}\text { Program Costs } \\
\text { of Eradication }\end{array}$ & $\begin{array}{c}\text { Citrus Canker } \\
\text { Research Funding }\end{array}$ & $\begin{array}{c}\text { Legal } \\
\text { Expenditures }\end{array}$ & $\begin{array}{l}\text { Total Cost of } \\
\text { CCEP }\end{array}$ \\
\hline & \multicolumn{5}{|c|}{ - \$1,000 --- } \\
\hline 1996 & -- & 3,080 & -- & -- & 3,080 \\
\hline 1997 & -- & 6,808 & -- & -- & 6,808 \\
\hline 1998 & -- & 13,836 & & -- & 13,836 \\
\hline 1999 & -- & 42,596 & -- & -- & 42,596 \\
\hline 2000 & 38,400 & 128,219 & -- & 5,200 & 171,819 \\
\hline 2001 & 38,400 & 94,540 & 4,750 & -- & 137,690 \\
\hline 2002 & -- & 79,856 & -- & -- & 79,856 \\
\hline 2003 & 11,800 & 68,699 & -- & -- & 80,499 \\
\hline 2004 & 16,598 & 39,718 & -- & -- & 56,316 \\
\hline 2005 & -- & 44,000 & -- & -- & 44,000 \\
\hline 2006 & -- & 22,800 & -- & -- & 22,800 \\
\hline 2007 & -- & 22,800 & -- & -- & 22,800 \\
\hline
\end{tabular}


Table 3. Benefit-cost analysis of the CCEP ${ }^{\mathrm{a}}$ (assuming a discount factor of 10 percent).

\begin{tabular}{|c|c|c|c|c|c|c|c|}
\hline Year & $\begin{array}{l}\text { Avoidance of } \\
\text { Annual Revenue } \\
\text { Loss and Cost } \\
\text { Savings (Benefits) }\end{array}$ & $\begin{array}{c}\text { Annual } \\
\text { Costs }\end{array}$ & $\begin{array}{l}\text { Discount } \\
\text { Factor } \\
(10 \%)\end{array}$ & $\begin{array}{c}\text { Discounted } \\
\text { Benefits }\end{array}$ & $\begin{array}{l}\text { Discounted } \\
\text { Costs }\end{array}$ & $\begin{array}{c}\text { Discounted } \\
\text { Net } \\
\text { Benefits }\end{array}$ & $\begin{array}{l}\text { Cumulative } \\
\text { Discounted } \\
\text { Net Benefits }\end{array}$ \\
\hline & \multicolumn{7}{|c|}{ - } \\
\hline 1996 & 254,195 & 3,080 & 0.9091 & 231,086 & 2,800 & 228,286 & 228,286 \\
\hline 1997 & 254,195 & 6,808 & 0.8264 & 210,079 & 5,626 & 204,452 & 432,738 \\
\hline 1998 & 254,195 & 13,836 & 0.7513 & 190,980 & 10,395 & 180,585 & 613,324 \\
\hline 1999 & 254,195 & 42,596 & 0.6830 & 173,619 & 29,094 & 144,525 & 757,849 \\
\hline 2000 & 254,195 & 171,819 & 0.6209 & 157,835 & 106,686 & 51,149 & 808,998 \\
\hline 2001 & 254,195 & 137,690 & 0.5645 & 143,486 & 77,722 & 65,764 & 874,762 \\
\hline 2002 & 254,195 & 79,856 & 0.5132 & 130,442 & 40,979 & 89,463 & 964,225 \\
\hline 2003 & 254,195 & 80,499 & 0.4665 & 118,584 & 37,553 & 81,030 & $1,045,256$ \\
\hline 2004 & 254,195 & 56,316 & 0.4241 & 107,803 & 23,883 & 83,920 & $1,129,176$ \\
\hline 2005 & 254,195 & 44,000 & 0.3855 & 98,003 & 16,964 & 81,039 & $1,210,215$ \\
\hline 2006 & 254,195 & 22,800 & 0.3505 & 89,094 & 7,991 & 81,103 & $1,291,317$ \\
\hline 2007 & 254,195 & 22,800 & 0.3186 & 80,994 & 7,265 & 73,730 & $1,365,047$ \\
\hline 2008 & & & & 890,938 & & 890,938 & $2,255,985$ \\
\hline Totals & & & & $2,622,944$ & 366,959 & $2,255,985$ & \\
\hline
\end{tabular}

Table 4. Analyzing CCEP benefits.

\begin{tabular}{|c|c|c|c|c|c|c|c|}
\hline \multicolumn{3}{|c|}{$\begin{array}{l}\text { A. Benefit-cost sensitivity analysis of CCEP, }{ }^{\text {a }} \\
\text { assuming discount factors of } 5 \%, 10 \% \text {, and } 15 \%\end{array}$} & \multicolumn{5}{|c|}{$\begin{array}{l}\text { B. Sensitivity analysis results of varying predicted benefits and } \\
\text { costs on the discounted net benefit of CCEP }\end{array}$} \\
\hline \multirow{2}{*}{$\begin{array}{c}\text { Discount } \\
\text { Factor }\end{array}$} & \multirow{2}{*}{$\begin{array}{l}\text { Discounted } \\
\text { Net Benefits }\end{array}$} & \multirow{2}{*}{$\begin{array}{c}\text { Change in } \\
\text { Discounted Net } \\
\text { Benefits }\end{array}$} & \multirow{5}{*}{$\begin{array}{c}\text { CCEP } \\
\text { Predicted } \\
\text { Net Costs } \\
\text { (\$Millions) }\end{array}$} & & \multicolumn{3}{|c|}{ CCEP Predicted Net Benefits (\$Millions) } \\
\hline & & & & & $75 \%$ & $100 \%$ & $125 \%$ \\
\hline $10 \%$ & $\$ 2,255,985$ & -- & & $75 \%$ & 1,692 & 2,348 & 3,003 \\
\hline $5 \%$ & $\$ 4,731,392$ & $\$ 2,475,407$ & & $100 \%$ & 1,600 & 2,256 & 2,912 \\
\hline $15 \%$ & $\$ 1,463,532$ & $-\$ 792,453$ & & $125 \%$ & 1,508 & 2,164 & 2,820 \\
\hline
\end{tabular}


Table 5. Yearly expenditures associated with the CCEP ${ }^{a}$ without "stop-and-go" approach to eradication.

\begin{tabular}{|c|c|c|c|c|c|}
\hline Year & $\begin{array}{c}\text { Producer } \\
\text { Compensation }\end{array}$ & $\begin{array}{c}\text { Program Costs } \\
\text { of Eradication }\end{array}$ & $\begin{array}{c}\text { Citrus Canker } \\
\text { Research } \\
\text { Funding } \\
\end{array}$ & $\begin{array}{c}\text { Legal } \\
\text { Expenditures }\end{array}$ & $\begin{array}{c}\text { Total Cost of } \\
\text { CCEP }\end{array}$ \\
\hline \multicolumn{6}{|c|}{ 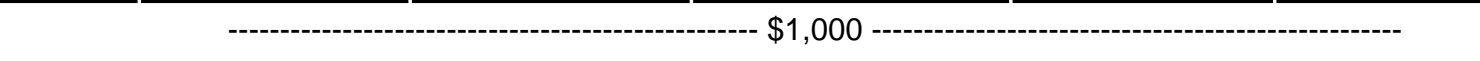 } \\
\hline 1996 & -- & 3,080 & -- & -- & 3,080 \\
\hline 1997 & -- & 6,808 & -- & -- & 6,808 \\
\hline 1998 & -- & 13,836 & -- & -- & 13,836 \\
\hline 1999 & -- & 42,596 & -- & -- & 42,596 \\
\hline 2000 & 38,400 & 128,219 & -- & -- & 166,619 \\
\hline 2001 & 38,400 & 22,800 & 4,750 & -- & 65,950 \\
\hline 2002 & -- & 22,800 & -- & -- & 22,800 \\
\hline
\end{tabular}

Table 6. Benefit-cost analysis of the CCEP ${ }^{a}$ (assuming successful completion in January of 2003).

\begin{tabular}{|c|c|c|c|c|c|c|c|}
\hline Year & $\begin{array}{l}\text { Avoidance of Annual } \\
\text { Revenue Loss and } \\
\text { Cost Savings } \\
\text { (Benefits) }\end{array}$ & $\begin{array}{c}\text { Annual } \\
\text { Costs }\end{array}$ & $\begin{array}{l}\text { Discount } \\
\text { Factor } \\
(10 \%)\end{array}$ & $\begin{array}{c}\text { Discounted } \\
\text { Benefits }\end{array}$ & $\begin{array}{l}\text { Discounted } \\
\text { Costs }\end{array}$ & $\begin{array}{c}\text { Discounted } \\
\text { Net } \\
\text { Benefits }\end{array}$ & $\begin{array}{l}\text { Cumulative } \\
\text { Discounted } \\
\text { Net Benefits }\end{array}$ \\
\hline & \multicolumn{7}{|c|}{ - 1,000 - } \\
\hline 1996 & 254,195 & 3,080 & 0.9091 & 231,086 & 2,800 & 228,286 & 228,286 \\
\hline 1997 & 254,195 & 6,808 & 0.8264 & 210,079 & 5,626 & 204,452 & 432,738 \\
\hline 1998 & 254,195 & 13,836 & 0.7513 & 190,980 & 10,395 & 180,585 & 613,324 \\
\hline 1999 & 254,195 & 42,596 & 0.6830 & 173,619 & 29,094 & 144,525 & 757,849 \\
\hline 2000 & 254,195 & 166,619 & 0.6209 & 157,835 & 103,457 & 54,378 & 812,226 \\
\hline 2001 & 254,195 & 65,950 & 0.5645 & 143,486 & 37,227 & 106,259 & 918,486 \\
\hline 2002 & 254,195 & 22,800 & 0.5132 & 130,442 & 11,700 & 118,742 & $1,037,228$ \\
\hline 2003 & & & & $1,434,865$ & 0. & $1,434,865$ & $2,472,093$ \\
\hline Totals & & & & $2,672,392$ & 200,300 & $2,472,093$ & \\
\hline
\end{tabular}

